\title{
THE INTERNATIONAL CRIMINAL COURT: A FAILURE OF INTERNATIONAL JUSTICE FOR VICTIMS?
}

\author{
KELISIANA THYNNE*
}

The International Criminal Court marked its tenth anniversary in 2008. In conjunction with that milestone, this article considers the status of international justice in the context of victims' rights in the Court's proceedings. The author presents a case study of the Thomas Lubanga Dyilo case and, in doing so, explores the reasons why the Court might already be failing to provide international justice for victims of international crimes. The article specifically discusses the rights of victims of gender-based crimes and the intersection between victims and justice in the Court. The author also offers suggestions of how the Court can better achieve international justice for victims as it moves forward with its first cases.
La Cour pénale internationale a marqué son dixième anniversaire en 2008. De concert avec ce grand événement, cet article examine l'état de la justice internationale à la lumière des droits des victimes dans les instances judicaires. L'auteur présente une étude de la cause Thomas Lubanga Dyilo et, en ce faisant, examine les raisons pour lesquelles la Cour pourrait déjà ne pas rendre justice internationale aux victimes de crimes internationaux. L'article traite tout particulièrement des droits des victimes des crimes fondés sur des motifs liés au sexe et le point de rencontre entre les victimes et la justice à la Cour. L'auteur fait aussi des suggestions sur la manière dont la Cour pourrait mieux rendre justice internationale aux victimes au moment de poursuivre ses premières causes.

\section{TABLE OF CONTENTS}

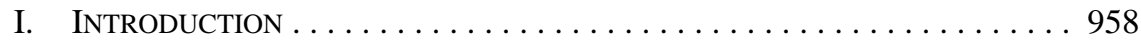

II. ESTABLISHING SOME NOTIONS OF INTERNATIONAL JUSTICE … . . . . . 959

III. WHAT WAS THE PROMISE OF THE COURT IN BRINGING INTERNATIONAL JUSTICE TO VICTIMS? . . . . . . . . . . . 962

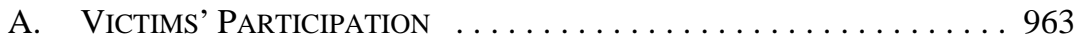

B. LEgAL REPRESENTATION OF Victims $\ldots \ldots \ldots \ldots \ldots \ldots \ldots . \ldots 96$

C. Victims of GENDER-BASEd CRIMES ................ 965

IV. THE LUBANGA CASE: A FAILURE OF INTERNATIONAL JUSTICE FOR VICTIMS? . . . . . . . . . . . . . . . 967

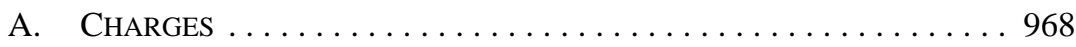

B. Victims' Participation $\ldots \ldots \ldots \ldots \ldots \ldots \ldots \ldots \ldots \ldots \ldots$

C. Victims' REPRESENTATION . ................... 973

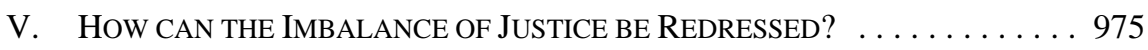

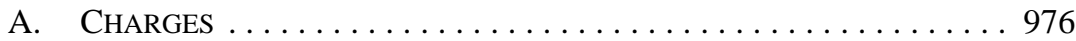

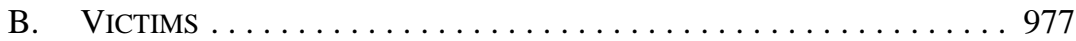

C. Alternatives Within THE COURT SYSTEM . . . . . . . . . . . . 979

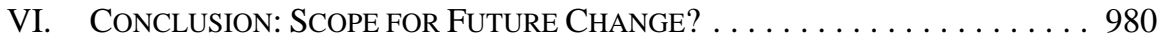

B.A. (Hons.), LL.B. (Hons.), Australian National University, LL.M., University of Sydney. Legal Adviser, International Committee of the Red Cross. The views expressed in this article are the author's own and do not represent in any way the views of the author's current or former employers. 


\section{INTRODUCTION}

The year 2008 marked the tenth anniversary of the adoption and the sixth anniversary of the entry into force of the Rome Statute of the International Criminal Court. ${ }^{1}$ The International Criminal Court (the Court) was lauded as a triumph of international justice and the beginning of the end to impunity for heinous international crimes. ${ }^{2}$ The Preamble to the Rome Statute provides that states parties are "Resolved to guarantee lasting respect for and the enforcement of international justice" 3 by accepting the Rome Statute and establishing the Court. The Rome Statute also contains many important new provisions to promote international justice, and includes a strong focus on gender, gender-based crimes, and victims’ rights and participation. ${ }^{4}$

The Prosecutor has opened investigations into four conflicts - the Democratic Republic of the Congo (DRC), the Central African Republic, Uganda, and Darfur, Sudan — and is considering at least six others at present. ${ }^{5}$ Three of the current situations are based on referrals from the states themselves, and one (Darfur) is a Security Council referral. ${ }^{6}$ The Court has charged 12 individuals with war crimes and crimes against humanity and has arrested four of these individuals; the trial for one of these, that of Thomas Lubanga Dyilo (the Lubanga case), was due to begin mid-2008. ${ }^{7}$ The Court stayed the case indefinitely on 13 June 2008 because it would have been prejudicial to the defendant to proceed. ${ }^{8}$ The Lubanga case has since been reopened and will proceed on different evidence. ${ }^{9}$ The Confirmation of Charges Hearing for two other joined cases, Germain Katanga and Mathieu Ngudjolo Chui, commenced on 27 June 2008 and concluded on 16 July 2008. ${ }^{10}$

17 July 1998, 2187 U.N.T.S. 3 (entered into force 1 July 2002) [Rome Statute].

See e.g. UN Secretary-General Kofi Annan, Address (Closing of the ninth session of the Preparatory Commission for the International Criminal Court, 19 April 2002), online: Coalition for the International Criminal Court <http://www.iccnow.org/documents/KofiAnnanPlenary19April02.pdf>.

Rome Statute, supra note 1, Preamble.

Susana SáCouto, “Advances and Missed Opportunities in the International Prosecution of Gender-Based Crimes” (2007) 15 MSU-DCL J. Int’l L. 137 at 139; Sylvia Pieslak, “The International Criminal Court’s Quest to Protect Rape Victims of Armed Conflict: Anonymity as the Solution,” Comment, (2004) 2 Santa Clara Journal of International Law 138 at 139.

These are Georgia, Colombia, Kenya, Cote d'Ivoire, Chad, and Afghanistan: International Criminal Court (ICC), Press Release, ICC-OTP-20080820-PR346, “ICC Prosecutor confirms situation in Georgia under analysis” (20 August 2008), online: ICC <http://www2.icc-cpi.int/Menus/ICC/Press+ and+Media/Press+Releases/Press+Releases+(2008)/> at 20.08.2008. Rome Statute, supra note 1, art. 13(b); SC Res. 1593, UN SCOR, 2005, UN Doc. S/RES/1593.

Prosecutor v. Thomas Lubanga Dyilo, ICC-01/04-01/06, Transcript (13 February 2008) at 4 (International Criminal Court, Trial Chamber I), online: ICC <http://www2.icc-cpi.int/iccdocs/doc/ doc439069.pdf>; see also Prosecutor v. Thomas Lubanga Dyilo, ICC-01/04-01/06, Decision on the consequences of non-disclosure of exculpatory materials covered by Article 54(3)(e) agreements and the application to stay the prosecution of the accused, together with certain other issues raised at the Status Conference on 10 June 2008 (13 June 2008) (International Criminal Court, Trial Chamber I), online: ICC <http://www2.icc-cpi.int/iccdocs/doc/doc511249.pdf> [Lubanga Stay of Prosecution]. Lubanga Stay of Prosecution, ibid.

International Criminal Court, Press Release, ICC-CPI-20081118-PR372, "Stay of proceedings in the Lubanga case is lifted - trial provisionally scheduled for 26 January 2009” (18 November 2008), online: ICC <http://www2.icc-cpi.int/Menus/ICC/Press+and+Media/Press+Releases/Press+Releases $+(2008) />$ at 8.11.2008.

Prosecutor v. Germain Katanga, ICC-01/04-01/07, Decision Establishing a Calendar according to the date of the Confirmation hearing: 27 June 2008 (29 April 2008) (International Criminal Court, Pre-Trial Chamber I), online: ICC < http://www2.icc-cpi.int/iccdocs/doc/doc480372.pdf>. At writing, the decision 
With such promise at the beginning for victims and women's rights, and with the commencement of cases now starting six years into the establishment of the Court, it is useful to consider whether the Court has yet served the interests of international justice for victims and particularly women victims.

The three people currently in The Hague charged with offences in relation to the conflict in the Ituri region of the DRC are only a very small representation of the commanders and soldiers who have allegedly committed serious crimes in the region. In addition, their charges are limited: Lubanga's relate to "thematic" charges of conscripting, enlisting, and using child soldiers, ${ }^{11}$ without any consideration given to the numerous gender-based crimes that allegedly occurred throughout the conflict. Those of Katanga and Ngudjolo relate to one incident in the entire conflict, involving the destruction of one village in Ituri. The Court in the Lubanga case recognized only four victims, and in the Katanga/Ngudjolo case only five. Further, while the Court has recognized 100 individuals as victims in the situation in the $\mathrm{DRC}$, their ability to participate in the trials and proceedings remains limited and generally unclear. $^{12}$

This article will explore notions of what international justice means in terms of victims' rights in the Court. Taking the case study of the Lubanga case, with its limited charges and lack of victim representation, the article explores why the Court at this early stage might already be in deficit with regard to providing international justice for victims of international crimes. It discusses the concept of victims' rights in the Court, in particular the rights of victims of gender-based crimes, and the intersection between victims and justice in the Court. It concludes with a reflection on whether the Court can achieve international justice for victims, with some suggestions as to how it could do so as it moves forward with its first cases.

\section{ESTABLISHING SOME NOTIONS OF INTERNATIONAL JUSTICE}

The Court's purpose is to achieve justice for the international community, for the relevant state, and for victims. Justice is essentially an abstract concept that can mean different things to different people depending on their contexts and the purposes for which they hope to use it. It is not the purpose of this section to define international justice, but rather to explore some aspects of international justice as perceived by different groups in order to determine the basis of international justice on which the Court was founded.

has not yet been handed down.

11 Prosecutor v. Thomas Lubanga Dyilo, ICC-01/04-01/06, Decision on the confirmation of charges (29 January 2007) (International Criminal Court, Pre-Trial Chamber I), online: ICC <http://www2.icc-cpi. int/iccdocs/doc/doc266175.pdf> [Lubanga Confirmation of Charges].

12 Situation en République Démocratique du Congo, ICC-01/04, Décision sur les demandes de participation à la procédure déposées dans le cadre de l'enquête en République démocratique du Congo par a/0004/06 à a/0009/06, a/0016/06 à a/0063/06, a/0071/06 à a/0080/06 et a/0105/06 à a/0110/06, a/0188/06, a/0128/06 à a/0162/06, a/0199/06, a/0203/06, a/0209/06, a/0214/06, a/0220/06 à a/0222/06, a/0224/06, a/0227/06 à a/0230/06, a/0234/06 à a/0236/06, a/0240/06, a/0225/06, a/0226/06, a/0231/06 à a/0233/06, a/0237/06 à a/0239/06 et a/0241/06 à a/0250/06 (24 December 2007) (Cour Pénale Internationale, La Chambre Préliminaire I), online: ICC <http://www2.icc-cpi.int/iccdocs/doc/doc 400706.pdf>. 
In international justice, the international community's goals include preserving international peace and security, ${ }^{13}$ ending impunity, and compensating for previous failure to act. ${ }^{14}$ The state in whose territory a war is fought or the crimes committed will also desire a role in justice to come to terms with the violence, seek retribution, or achieve reconciliation. ${ }^{15}$ Non-governmental organizations (NGOs) also want to see justice done and are using various ways of becoming involved in the justice process, from representing victims, to promoting victims' rights, to bringing information to the attention of the Prosecutor. $^{16}$

Significantly, John Rawls has argued that

[t]hose who hold different conceptions of justice can ... still agree that institutions are just when no arbitrary distinctions are made between persons in the assigning of basic rights and duties and when the rules determine a proper balance between competing claims to the advantages of social life. ${ }^{17}$

He says that a sense of justice leads people to attempt to establish just institutions. ${ }^{18}$ The Court was set up as a judicial process to achieve justice. The notion of "international justice" — its enforcement and its maintenance - is a pillar on which it is built. Despite different perspectives of what justice may mean, in establishing the Court there was general agreement that international justice meant several things. These included bringing an end to impunity for all people who commit heinous crimes; prosecuting people for such crimes; bringing the voices of the state, rebel groups, and victims who were affected in a conflict to the ears of the international community; and acting as a deterrent for future conflicts and crimes. ${ }^{19} \mathrm{In}$ order to achieve these goals, the notion of justice in the Court was founded on a Western liberal-democratic sense of justice, meaning that the procedures to achieve justice are fair, objective, consistent, impartial, and based on the rule of law. ${ }^{20}$

Of course, justice and democracy do not necessarily go hand in hand. It is possible to have justice without democracy and democracy without justice. ${ }^{21}$ Therefore, the notion of giving victims a voice, which could be described as a means of bringing some participatory democracy to the Court's functioning, may not sit well with ultimately achieving

13 Bruce Broomhall, International Justice and the International Criminal Court: Between Sovereignty and the Rule of Law (Oxford: Oxford University Press, 2003) at 10.

$14 \quad$ Susan Lamb, "Pious Hope or Realist Instrument? Challenges from the Pursuit of International Criminal Justice” in David B. MacDonald, Robert G. Patman \& Betty Mason-Parker, eds., The Ethics of Foreign Policy (Burlington, Vt.: Ashgate, 2007) 221 at 222.

15 See Katherine M. Franke, “Gendered Subjects of Transitional Justice” (2006) 15 Colum. J. Gender \& L. 813 at 813, 823; Jackson Nyamuya Maogoto, "International Justice for Rwanda Missing the Point: Questioning the Relevance of Classical Criminal Law Theory” (2001) 13 Bond Law Review 190 at 211, 214, 217.

16 See e.g. Allison Marston Danner, "Enhancing the Legitimacy and Accountability of Prosecutorial Discretion at the International Criminal Court” (2003) 97 A.J.I.L. 510 at 533.

17 John Rawls, A Theory of Justice (Cambridge: Harvard University Press, 1971) at 5.

$18 \quad$ Ibid. at 474

19 Rome Statute, supra note 1, Preamble.

$20 \quad$ See Broomhall, supra note 13 at 52; see also Rawls, supra note 17 at 60; Antonio Cassese, International Criminal Law, 2d ed. (Oxford: Oxford University Press, 2008) at 439.

21 Keith Dowding, “Are Democratic and Just Institutions the Same?” in Keith Dowding, Robert E. Goodin \& Carole Pateman, eds., Justice \& Democracy (Cambridge: Cambridge University Press, 2004) 25 at 25. 
international justice. International law and its institutions have rarely been described as democratic. $^{22}$ The Court is no exception. Established by state consensus in an international forum, it does not represent the views of the people of the world in its establishment. ${ }^{23}$ In its structures, elements of democracy are missing: for example, there is a lack of accountability in the Office of the Prosecutor, and a lack of a separation of powers between the Court, the Defence, and the victims.

It is beyond the scope of this article to discuss these issues, but there is room for future discussion about whether the state-based nature of the Rome Statute and the role of the Security Council as a referral body politicize the Court. Moreover, the use of the Court by various member and non-member states as a political bargaining tool, the lack of enforcement mechanisms in the Court, and the high levels of prosecutorial discretion have already limited democracy in the Court and thus limited the achievement of international justice. ${ }^{24}$ Nonetheless, the Rome Statute does give more credence to the notion that the Court would provide international justice to the international community by giving particular weight to the voices of those persons directly affected by the crimes with which the Court deals, namely the victims.

A common problem with liberal-democratic notions of justice is that they tend to deny justice to women because democracies were male and public domains, with women and the private sphere out of the public democratic picture. ${ }^{25}$ Similarly, in accordance with traditional liberal notions, criminal justice is characterized by distance between the accused, the victims, and the punishment. ${ }^{26}$ The relationship becomes one between the government or court and the defendant, without recognizing other persons and factors in issue. ${ }^{27}$ Feminists have argued for greater engagement, greater discussion, and a greater voice to be given to underrepresented people in criminal justice. ${ }^{28}$ Victims and their experiences are marginalized to a certain extent by the fact that they are termed "victims.” They are thereby already relegated to a particular private sphere, in need of protection, and without an adequate voice. ${ }^{29}$ They need to have an opportunity to engage with the Court system and have their experiences respected and accepted.

See e.g. Craig Forcese, "Hegemonic Federalism: The Democratic Implications of the UN Security Council’s ‘Legislative’ Phase” (2007) 38 V.U.W.L.R. 175 at 176.

Madeline H. Morris, “Democracy, Global Governance and the International Criminal Court” in Ramesh Thakur \& Peter Malcontent, eds., From Sovereign Impunity to International Accountability: The Search for Justice in a World of States (Tokyo: United Nations University Press, 2004) 187 at 190.

See e.g. Broomhall, supra note 13 at 57, 68; Danner, supra note 16; Richard John Galvin, "The ICC Prosecutor, Collateral Damage, and NGOs: Evaluating the Risk of a Politicized Prosecution” (2005) 13 U. Miami Int'l \& Comp. L. Rev. 1. Keith Dowding, Robert E. Goodin \& Carole Pateman, "Introduction: Between Justice and Democracy” in Dowding, Goodin \& Pateman, supra note 21, 1 at 11 [Dowding, Goodin \& Pateman, "Introduction”]. Heather Strang, Repair or Revenge: Victims and Restorative Justice (Oxford: Clarendon Press, 2002) at 1.

Maogoto, supra note 15 at 218.

Dowding, Goodin \& Pateman, "Introduction," supra note 25 at 12.

See Hilary Charlesworth \& Christine Chinkin, The Boundaries of International Law: A Feminist Analysis (Manchester: Manchester University Press, 2000) at 48. 
The Court, through the Rome Statute and Rules of Procedure and Evidence, ${ }^{30}$ attempts to address this imbalance by providing for the rights of the accused, the right to a fair trial, and the rule of law, while also providing a voice for women and victims (both men and women). It is characterized by an attempt towards accountability and an end to impunity. ${ }^{31}$ The purpose of international trials is "not so much retribution as stigmatization of deviant behaviour,"32 as well as making persons responsible for crimes they have committed. Greater accountability can lead to a greater affirmation of the "dignity of the victims," "social healing," and "historical rectification," 33 which are all goals of international justice. ${ }^{34}$ The Rome Statute, in particular, focuses on the rights of victims in terms of justice. Articles 53(3) and 65(4), for example, provide for the interests of victims to be taken into account when assessing the interests of justice. The Prosecutor must decide whether to proceed in an investigation based on the interests of justice, taking into account, among other things, the interests of the victims. This approach is consistent with the increasing role victims want in obtaining justice. The following section considers the promise of international justice given to victims before the Court.

\section{What WAS The Promise OF The Court IN BRINGING INTERNATIONAL JUSTICE TO VICTIMS?}

Coming from civil and common law justice systems where criminal justice involves an offence against the state rather than an individual ${ }^{35}$ and victims have rarely been given a role, ${ }^{36}$ the tendency has traditionally been to characterize international crimes as crimes against the international community rather than victims. ${ }^{37}$ The Court seeks to rectify that by having international justice for victims. Opening the final United Nations Diplomatic Conference of Plenipotentiaries on the Establishment of an International Criminal Court, then United Nations Secretary-General Kofi Annan said that in achieving international justice:

[T] he overriding interest must be that of the victims, and of the international community as a whole. I trust you will not flinch from creating a court strong and independent enough to carry out its task. It must be an instrument of justice, not expediency. It must be able to protect the weak against the strong. ${ }^{38}$

International Criminal Court, Rules of Procedure and Evidence, online: ICC <http://www2.icccpi.int/Menus/ICC/Legal+Texts+and+Tools/Official+Journal/Rules+of+Procedure+and+ Evidence.htm>.

Broomhall, supra note 13 at $67,189$.

Cassese, supra note 20 at 440.

Broomhall, supra note 13 at 55.

See Martti Ahtisaari, “Preface: Justice and Accountability: Local or International?” in Thakur \& Malcontent, supra note 23, xii at xv.

In civil law proceedings, victims can be represented, but they have the role of witnesses and assistants in the seeking of truth in the inquisitorial system. Their role is not as participative as that of victims under the Rome Statute.

Strang, supra note 26 at 5.

Gerry Simpson, Law, War and Crime (Cambridge, U.K.: Polity Press, 2007) at 51.

UN Secretary-General Kofi Annan, Opening Statement (United Nations Diplomatic Conference of Plenipotentiaries on the Establishment of an International Criminal Court, 15 June 1998), online: UN <http://www.un.org/News/ossg/sg/stories/statments_search_full.asp?statID=46>. 
The Rome Statute set out the most advanced provisions yet to be seen in international criminal law on the protection of victims and the inclusion of victims in the justice process. ${ }^{39}$ This was despite controversy over the involvement of victims during negotiations of the Rome Statute, ${ }^{40}$ particularly in relation to whether justice should be restorative or retributive. ${ }^{41}$ For the first time, victims can participate directly in criminal proceedings internationally. ${ }^{42}$ The Rome Statute attempts to combine the need to "see justice being done" with the justice process by incorporating victims' participation and representation into the process.

\section{A. Victims' Participation}

The Rome Statute provides for the right of victims to be recognized and to participate in the trial, thus giving them direct access to international justice. Victims are "natural persons" or particular organizations and institutions that have "suffered harm as a result of the commission of any crime within the jurisdiction of the Court." ${ }^{\text {"3 }}$ They can participate at all stages of the proceedings, on the face of the Statute. The Court has three chambers. ${ }^{44}$ The Pre-Trial Chamber assesses the validity of charges and is involved in the investigation (or the situation) phase. ${ }^{45}$ The Trial Chamber ${ }^{46}$ conducts the trial in accordance with those charges (the prosecution phase). The Appeals Chamber hears appeals from both the Prosecutor and Defence on errors of law or fact. ${ }^{47}$ Victims can make representations at all stages, in accordance with the Rules and Procedures of Evidence, including on issues of jurisdiction and admissibility. ${ }^{48}$ Their representations must be limited to the issues that the relevant Chamber is considering and must demonstrate how their personal interests are affected. $^{49}$

Victims can also receive reparations at the end of the trial. ${ }^{50}$ This will provide them with compensation for the suffering that they have undergone as victims of crimes under the jurisdiction of the Court. Victims have a role in assisting the Court to determine the amount of reparations by making submissions to the Chamber. ${ }^{51}$ They can also appeal reparation

Ilaria Bottigliero, Redress for Victims of Crimes Under International Law (Leiden: Martinus Nijhoff, 2004) at 213.

William A. Schabas, An Introduction to the International Criminal Court (Cambridge: Cambridge University Press, 2001) at 146.

Bottigliero, supra note 39 at 214.

Prosecutor v. Thomas Lubanga Dyilo, ICC-01/04-01/06, Judgment on the appeals of The Prosecutor and The Defence against Trial Chamber I's Decision on Victims' Participation of 18 January 2008 (11 July 2008) at para. 96 (International Criminal Court, Appeals Chamber), online: ICC <http://www2.icccpi.int/iccdocs/doc/doc529076.pdf> [Lubanga Appeal]; Rome Statute, supra note 1, art. 68(3).

Rules and Procedures of Evidence, supra note 30, r. 85(a).

Rome Statute, supra note 1, arts. 34, 39.

Ibid., arts. 56-57.

Ibid., art. 64.

Ibid., art. 81.

Ibid., arts. 15(3), 19(3), 53.

Prosecutor v. Thomas Lubanga Dyilo, ICC-01/04-01/06, Decision, in limine, on Victim Participation in the appeals of the Prosecutor and the Defence against Trial Chamber I's Decision entitled "Decision on Victims’ Participation” (16 May 2008) at para. 50 (International Criminal Court, Appeals Chamber), online: ICC <http://www2.icc-cpi.int/iccdocs/doc/doc493169.pdf>.

Rome Statute, supra note 1, art. 75.

Ibid., art. 75(3). 
decisions. ${ }^{52}$ In the final sentencing process, victims' participation is, however, limited to the question of reparations. ${ }^{53}$

The Appeals Chamber in the Lubanga case held that although "the right to lead evidence pertaining to the guilt or innocence of the accused and the right to challenge the admissibility or relevance of evidence in trial proceedings lies primarily with the parties," 54 victims can also lead evidence. ${ }^{55}$ The Chamber held that it would be contrary to the spirit of the victims' participation provisions for victims not to be able to lead evidence as to the guilt of the accused where the victims' personal interests are in issue. ${ }^{56}$ In the latest victims' participation decision by the Appeals Chamber in the Lubanga case, the Court gave the strongest endorsement of victims' rights and the need for them to participate meaningfully in the trial process in order to secure international justice for themselves. ${ }^{57}$ Whether this promise has been met will be considered below in the context of the Lubanga case.

\section{B. LEGAL REPRESENTATION OF VICTIMS}

The Court gives victims particular assistance in obtaining representation and in the process of investigations and trials, which gives the victims greater access to justice than might be found were they to be left to argue their rights alone. Article 43(6) of the Rome Statute establishes the Victims and Witnesses Unit to provide "protective measures and security arrangements, counselling and other appropriate assistance for witnesses, [and] victims who appear before the Court."58 They include people with specific expertise on trauma and gender-based crimes. Within the unit, the Victims' Participation and Reparation Section (Victims' Section) assists victims in keeping them as fully informed as possible about the process of the Court and what their role is. ${ }^{59}$ They process victims' applications and assist them in finding appropriate legal representation.

The Office of the Public Counsel for Victims (Victims' Counsel) also assists victims. The Victims' Counsel is an independent body initially established to provide research and legal advice in support of victims' interests and rights before the Court, even when there are no victims. ${ }^{60}$ Now that victims are playing a greater role in the Court, the Victims' Counsel represents all potential victims in court before their applications have been assessed. The Victims' Counsel can represent victims once they have been recognized if the victims so

Ibid., art. 84(2).

Ibid., art. 76(3).

Lubanga Appeal, supra note 42 at para. 93.

Ibid. at para. 94.

Ibid. at para. 97.

Ibid. at para. 96.

Rome Statute, supra note 1, art. 43(6).

International Criminal Court, Participation of Victims in Proceedings, online: ICC <http://www2.icccpi.int/Menus/ICC/Structure+of+the+Court/Victims/Participation>.

60 International Criminal Court, Regulations of the Court, reg. 81 (entered into force 26 May 2004), online: ICC <http://www2.icc-cpi.int/Menus/ICC/Legal+Texts+and+Tools/Official+Journal/ Regulations+of+the+Court.htm>. 
choose and the expertise of the Victims' Counsel is particularly needed. ${ }^{61}$ NGOs also support victims in their search for legal representation and work with them in the field.

In spite of the resources that are put towards victim representation, victims are separated from the court process by the need for this legal representation, and also by the fact that they are in a different country, far from the Court. Yet they must interact with the Court at each point at which they wish to demonstrate that their personal interests are affected. ${ }^{62}$ The distance between them, the legal procedures, and ultimately the Court means that the process will be ultimately meaningless to them and their access to international justice limited despite the assistance given to them. The particular problems that have been highlighted in the Lubanga case are discussed below.

\section{VICTIMS OF GENDER-BASED CRIMES}

The Rome Statute is groundbreaking in its references to "gender" and crimes against women. ${ }^{63}$ It goes beyond previous international criminal statutes in establishing jurisdiction over more international gender-based crimes ${ }^{64}$ and provides women with a greater voice in the justice process. This supposedly ensures greater international justice to women and to all victims of gender-based crimes. Victims are to be treated with respect and account is to be taken of their gender when the Court provides them with protection, assistance, and a role in the trial and investigation. ${ }^{65}$ In particular, art. 54(1)(b) provides that

\footnotetext{
[t]he Prosecutor shall ... [t]ake appropriate measures to ensure the effective investigation and prosecution of crimes within the jurisdiction of the Court, and in doing so, respect the interests and personal circumstances of victims and witnesses, including age, [and] gender ... and take into account the nature of the crime, in particular where it involves sexual violence, gender violence or violence against children. ${ }^{66}$
}

Article 7(3) rather controversially defines gender as "the two sexes, male and female, within the context of society," potentially limiting gender to a biological division rather than its more usual meaning of a social construction; it might also be intended to exclude consideration of sexual identity or orientation. ${ }^{67}$ The Court has not yet addressed "gender" in any context, but it is likely the Court would consider gender broadly in line with existing

Prosecutor v. Thomas Lubanga Dyilo, ICC-01/04-01/06, Decision on the role of the Office of Public Counsel for Victims and its request for access to documents (6 March 2008) at para. 34 (International Criminal Court, Trial Chamber I), online: ICC <http://www2.icc-cpi.int/iccdocs/doc/doc451768.pdf>; Regulations of the Court, ibid., reg. 80(2).

62 Rules of Procedure and Evidence, supra note 30, r. 89.

63 This was mostly thanks to the work of NGOs: Rana Lehr-Lehnardt, "One Small Step for Women: Female-Friendly Provisions in the Rome Statute of the International Criminal Court” (2002) 16 B.Y.U.J. Pub. L. 317 at 318; Lindsay Peterson, "Shared Dilemmas: Justice for Rape Victims under International Law and Protection for Rape Victims Seeking Asylum,” Note, (2008) 31 Hastings Int'l \& Comp. L. Rev. 509 at 520.

64 Christine Chinkin, “Gender-related Crimes: A Feminist Perspective” in Thakur \& Malcontent, supra note 23,116 at 117 .

65 Rome Statute, supra note 1, arts. 54(1)(b), 68(1).

$66 \quad$ Ibid., art. 54(1)(b).

67 Valerie Oosterveld, “The Definition of 'Gender' in the Rome Statute of the International Criminal Court: A Step Forward or Back for International Criminal Justice?” (2005) 18 Harv. Hum. Rts. J. 55 at 57, 65, 71. 
definitions of the word in international law. ${ }^{68}$ The purpose of the inclusion of the word gender was partly to ensure that victims have equal representation and have greater access to justice than ever before. The treatment of women within armed conflicts should be on an equal basis with men, in contrast to the previous experience of women in armed conflict. ${ }^{69}$ The experiences of women and men who are victims of sexual and gender-based violence should be recognized by the Court under the Rome Statute so as to empower women in particular, who already face powerlessness as a result of the gender-based violence, but also as a cause of gender-based violence. ${ }^{70}$

The application of the laws under the Rome Statute must be consistent with international law, including non-discrimination on the basis of gender. ${ }^{71}$ Such laws include gender-based crimes of rape, sexual violence, sexual slavery, prostitution, and forced pregnancy as crimes against humanity and as war crimes. ${ }^{72}$ The Court is also supposed to ensure greater recognition of gender and gender-based violence by appointing to the Office of the Prosecutor an expert on sexual and gender violence ${ }^{73}$ and ensuring that the Victims and Witnesses Unit has staff with gender expertise. ${ }^{74}$ It was felt during negotiations of the Rome Statute that without such expertise, important information and evidence may be overlooked during investigations and prosecution. ${ }^{75}$ However, the Prosecutor has only very recently appointed a Gender Advisor ${ }^{76}$ and this lack of expertise until now was evident in the application of the provisions of the Rome Statute related to victims and gender to the crimes, investigations, and prosecutions. As discussed in the next section, the gendered nature of many of the crimes before the Court has not yet been considered. Also, recognition has been given to very few women victims whose experience of international justice through the Court will necessarily be very different from that of men.

Ibid. at 73.

See Judith Gardam, “Women and the Law of Armed Conflict: Why the Silence?” (1997) 46 I.C.L.Q. 55 at 56.

Charlesworth \& Chinkin, supra note 29 at 13.

Rome Statute, supra note 1, art. 21(3).

Ibid., arts. 7(1)(g), 7(1)(h), 8(2)(b)(xxii), 8(2)(e)(vi).

Ibid., art. 42(9).

Ibid., art. 43(6).

Valerie Oosterveld, “Gender-Sensitive Justice and the International Criminal Tribunal for Rwanda: Lessons Learned for the International Criminal Court” (2005) 12 New Eng. J. Int'l \& Comp. L. 119 at 128 [Oosterveld, “Gender-Sensitive Justice”].

International Criminal Court, Press Release, ICC-OTP-20081126-PR377, "ICC Prosecutor Appoints Prof. Catharine A. MacKinnon as Special Adviser on Gender Crimes” (26 November 2008), online: ICC $<$ http://www2.icc-cpi.int/Menus/ICC/Press+and+Media/Press+Releases/Press+Releases+(2008)/> at 26.11.2008. 


\section{The lubanga Case: A Failure of INTERNATIONAL JUSTICE FOR VICTIMS?}

While there have always been problems with the notion of direct participation of victims in the Court, the Lubanga case has highlighted early problems for victims' access to international justice in the Court. On 10 February 2006, a warrant for the arrest of Thomas Lubanga Dyilo (Lubanga) was issued by the Court. ${ }^{77}$ Lubanga was the alleged President of the Union des Patriotes Congolais/Réconciliation et Paix (UPC/RP), which took control of Bunia, the capital of the Ituri district in the DRC. ${ }^{78}$ He was arrested on 17 March $2006^{79}$ and his Confirmation of Charges hearing was held between 9 and 28 November 2006.

The trial was due to start on 13 June 2008, but was stayed on the basis that the Prosecutor failed "to disclose to the accused potentially exculpatory materials covered by agreements entered into pursuant to Article 54(3)(e) of the Rome Statute." ${ }^{80}$ Article 54(3)(e) provides that the Prosecutor can enter into an agreement with persons providing documentary evidence (such as the UN or NGOs), that he or she will not disclose that information, and that the documents are to be used only for generating other evidence. The Court held that the Prosecutor, in failing to disclose up to 200 documents that could have been exculpatory for the defendant on the basis of this provision both to the Court and the defendant, was acting contrary to the right to a fair trial. The Court concluded that the proceedings would have to be stayed indefinitely. ${ }^{81}$ In November 2008, the case was reopened and will proceed in 2009.

This was the first case to come before the Court trying a person for war crimes arising out of a conflict that has been recognized as one of the most sexually abusive armed conflicts ever, and which also caused the displacement of thousands of people and the deaths and injury of many more. ${ }^{82}$ It was the first chance for the Court to demonstrate its commitment to international justice, particularly to demonstrate a commitment to respecting the dignity and voice of victims. However, in refusing to consider further charges, in limiting the number of victims in the case, and in demonstrating difficulties in victim participation in general, the Court has so far failed victims. The Court itself has acknowledged this failure: "The judges are acutely aware that by staying these proceedings the victims have, in this sense, been excluded from justice." 83 The reopening of the case will give the victims access to justice in a limited sense, but the existing problems of victim recognition in the Lubanga case could remain the same unless a different approach is taken. (International Criminal Court, Pre-Trial Chamber I), online: ICC < http://www2.icc-cpi.int/iccdocs/doc/ doc191959.pdf>.

78 Lubanga Confirmation of Charges, supra note 11 at para. 8.

$79 \quad$ Ibid. at para. 18.

$80 \quad$ Lubanga Stay of Prosecution, supra note 7 at para. 1.

$81 \quad$ Ibid. at para. 94.

82 Letter from the Secretary-General to the President of the Security Council (16 July 2004), UN Doc. S/2004/573, online: UN <http://www.un.org/Docs/sc/unsc_presandsg_letters04.html> [UNSG Letter]. 


\section{A. Charges}

Lubanga was charged with six offences: the three counts of enlisting child soldiers applied to both an international and a non-international armed conflict. ${ }^{84}$ These charges demonstrate the determination of the international community to stop the serious crime of using children in armed conflict. ${ }^{85}$ But they fail to recognize most of the other crimes that Lubanga has potentially committed in the DRC, including gender-based crimes against child soldiers and against women and men in the conflict. ${ }^{86}$ As a commander, Lubanga was arguably responsible for the actions of his subordinates in the UPC/RP, as well as participating directly in the conflict himself. The UPC/RP was responsible for thousands of rapes and murders of civilians, as well as the forcible use of child soldiers throughout the 2002-2003 armed conflict in the DRC. ${ }^{87}$ Therefore, not only should the use of child soldiers be an issue in the Lubanga case, but also sexual violence and other violence. The fact that these charges were not brought in the Lubanga case means that the Court is excluding consideration of the major aspects of the conflict with which they are supposed to be dealing. In so doing, they are excluding the victims of all of these other crimes.

It has been argued that international justice is necessarily selective justice. ${ }^{88}$ The choice of situations that the Court is investigating is selective, as are the defendants that the Court (or Prosecutor) is choosing to prosecute. In the Court, there is also the selective use of evidence and gathering of evidence, as seen in the events that led to the stay of proceedings. With the narrow charges, the Court is once again engaging in a "selective form of justice" 89 by limiting the scope and nature of the crimes that it is willing to consider in the situation in the DRC.

There is a balance to be reached between the expediency of a first trial and achieving justice for victims. In relation to the Karadzic trial currently ongoing in the International Criminal Tribunal for the Former Yugoslavia, international criminal law expert, Antonio Cassese, has been reported as saying:

The prosecution will have to narrow its case.... In any event, the court cannot satisfy all the victims and prosecute thousands of people in all the places. The court has to make choices, so it is best to choose for an effective trial. $^{90}$

Lubanga Confirmation of Charges, supra note 11; Rome Statute, supra note 1, arts. 8(2)(b)(xxvi), 8(2)(e)(vii).

85 Nienke Grossman, "Rehabilitation or Revenge: Prosecuting Child Soldiers for Human Rights Violations” (2007) 38 Geo. J. Int'l L. 323 at 359.

86 Luis Moreno-Ocampo, Address (Third Session of the Assembly of States Parties to the Rome Statute of the International Criminal Court, The Hague, 6 September 2004), online: ICC <http://wwwold.icccpi.int/library/asp/LMO_20040906_En.pdf>; Human Rights Watch, “International Criminal Court Trial of Thomas Lubanga,” online: Human Rights Watch <http://www.hrw.org/en/news/2009/01/22/ international-criminal-court-trial-thomas-lubanga>.

Ibid. at 18.

Cited in Marlise Simons, “Karadzic Makes Court Appearance” The New York Times (1 August 2008), online: New York Times <http://www.nytimes.com/2008/08/01/world/europe/olhague.html>. 
It may be best to choose an effective trial — although in Lubanga's case, the trial has been so ineffective it has not properly started. Within the bounds of an effective trial, particularly in the Court, the rights and interests of victims and the gender provisions of the Rome Statute must be taken into account when framing the charges. Limiting charges and shortening indictments has been shown to produce shorter and more focused cases, but this is sometimes to the exclusion of gender-based crimes. ${ }^{91}$

In addition to the status given to victims in the Rome Statute in terms of participation in and access to international justice, the nature of the charges affects the way that victims can participate. The Appeals Chamber has held that harm must be as a result of the crimes charged and not the general crimes under the jurisdiction of the Court:

If the applicant is unable to demonstrate a link between the harm suffered and the particular crimes charged, then even if his or her personal interests are affected by an issue in the trial, it would not be appropriate under article 68 (3) read with rule 85 and 89 (1) of the Rules for his or her views and concerns to be presented. ${ }^{92}$

The Women's Initiatives for Gender Justice, a Hague-based NGO, presented an amicus curiae brief to the Pre-Trial Chamber in 2006, requesting leave to address the Court on why it should ask the Prosecutor to expand the charges against Lubanga. ${ }^{93}$ The Women's Initiatives also submitted a confidential document detailing 55 interviews with victims of gender-based violence in the Ituri region in the DRC. ${ }^{94}$ Their argument was that the Court has the power to ask the Prosecutor to conduct further investigations and to amend the charges. ${ }^{95}$ Based on the evidence, they argued that there were serious gender-based crimes committed in the DRC by UPC/RP forces, including Lubanga. They proposed that the charges be amended to take this into account. ${ }^{96}$

The Court held that the request by the Women's Initiatives to expand the charges had no link to the case against Lubanga, as the charges were limited to child soldiers, not to genderbased crimes. ${ }^{97}$ The Court displayed a narrow approach to the nature of the charges and to their responsibility to consider whether the charges are appropriate. By refusing to consider, first, that gender-based crimes could be encompassed under the current charges and, second, that the charges could be changed to include war crimes and crimes against humanity of gender-based crimes, the Court effectively refused to consider the harm caused to most victims of Lubanga, the UPC/RP, and the surrounding conflict. This excludes a whole group of victims from international justice.

Oosterveld, “Gender-Sensitive Justice,” supra note 75 at 131-32.

Lubanga Appeal, supra note 42 at para. 64.

Prosecutor v. Thomas Lubanga Dyilo, ICC-01/04-01/06, Request submitted pursuant to Rule 103(1) of the Rules of Procedure and Evidence for Leave to Participate as Amicus Curiae in the Article 61 Confirmation Proceedings (with Confidential Annex 2) (7 September 2006) (International Criminal Court, Pre-Trial Chamber I), online: ICC <http://www2.icc-cpi.int/iccdocs/doc/doc192717.pdf>.

Ibid.

Ibid. at paras. 7-8.

Ibid. at para. 8 .

Prosecutor v. Thomas Lubanga Dyilo, ICC-01/04-01/06, Decision on Request pursuant to Rule 103 (1) of the Statute (26 September 2006) at 3 (International Criminal Court, Pre-Trial Chamber I), online: ICC <http://www2.icc-cpi.int/iccdocs/doc/doc192882.pdf>. 
The charges, in particular, fail to take into account the experience of women victims and all those suffering gender-based violence in the conflict. The charges and crimes privilege the experience of the male soldier, combatant, and fighter over that of the woman soldier, sex slave, and domestic servant. Even though the charges relate to child soldiers, a group which should include girls, the approach that has been taken in international criminal jurisprudence in relation to child soldiers has focused on the male child soldiers; female soldiers are "subsumed" under this category and their experiences marginalized. ${ }^{98}$ The Court's willingness to accept a limited definition of using children to participate in armed conflict ${ }^{99}$ indicates that it will follow the narrow interpretation of other international courts.

Further, the charges mean the Court will fail to recognize the dual roles that women often play in such a conflict ${ }^{100}$ and the further implications of gender-based violence on women in particular, ${ }^{101}$ such as exposure to pregnancy, disease, emotional suffering, and stigmatization. ${ }^{102}$ Women victims have been effectively sidelined from the process because of the focus on fighting, the conflict, and the public nature of these acts, as well as the gendered focus that relates them to men and the experiences of male child soldiers. ${ }^{103}$ The Court will not address the private nature of domestic service and sexual violence. This is an indication of the disregard that the Court is paying to justice for victims of gender-based crimes. It fails all of these victims in achieving international justice.

The charges have remained the six original charges and there is no indication that they will be expanded or adapted. Indeed, the Prosecutor has indicated that he will not expand the charges because of security concerns to the victims themselves. ${ }^{104}$ The charges are directed at serious crimes and it is important to provide justice for the children who were used as child soldiers, ${ }^{105}$ but the way the Court has dealt with them indicates that the Court intends to keep the bounds of the crimes narrow. Therefore, the scope for victim participation and, thus, their access to international justice will be, and has already been, very narrow.

\section{B. Victims’ Participation}

The Lubanga case, as the first case before the Court, represented an opportunity for the Court to demonstrate the extent of victims' participation. But before the start and then the stay of the trial, only four victims had been recognized as victims of the case and able to

Augustine S.J. Park, “'Other Inhumane Acts’: Forced Marriage, Girl Soldiers and the Special Court for Sierra Leone” (2006) 15 Soc. \& Leg. Stud. 315 at 316, 322.

Lubanga Confirmation of Charges, supra note 11 at para. 262.

See Prosecutor v. Thomas Lubanga Dyilo, ICC-01/04-01/06, Annex A, Submission of the Observations of the Special Representative of the Secretary General of the United Nations for Children and Armed Conflict pursuant to Rule 103 of the Rules of Procedure and Evidence (18 March 2008) at para. 22, (International Criminal Court, Trial Chamber I), online: ICC <http://www2.icc-cpi.int/iccdocs/doc/ doc457039.pdf $>$ [Lubanga Special Representative Annex A].

Chinkin, supra note 64 at 116.

Park, supra note 98 at 322.

See Charlesworth \& Chinkin, supra note 29 at 49; Gardam, supra note 69 at 70.

Katy Glassborow, “ICC Inquiries Jeopardised” (6 July 2006), online: Institute for War and Peace Reporting <http://www.iwpr.net/?p=acr\&s=f\&o=322097\&apc_state=heniacr2006>.

Basic Principles and Guidelines on the Right to a Remedy and Reparation for Victims of Gross Violations of International Human Rights Law and Serious Violations of International Humanitarian Law, GA Res. 60/147, UN GAOR, 60th Sess., UN Doc. A/RES/60/147 (2006) at 3. 
participate in the proceedings. ${ }^{106}$ The Court has identified a difference between victims of the situation and victims of the case. Victims of the situation are able to participate (once recognized as victims by the Court) in the investigation of the case and in the Pre-Trial phase. Victims of the case must be victims of the crimes for which the accused is charged. ${ }^{107}$ The Trial Chamber in the Lubanga case held that

a victim of any crime falling within the jurisdiction of the Court can potentially participate. However, selfevidently, it would not be meaningful or in the interests of justice for all such victims to be permitted to participate as victims in the case against Mr Thomas Lubanga Dyilo, given that the evidence and the issues falling for examination in the case (which will be dependent on the charges he faces) will frequently be wholly unrelated to the crimes that caused harm to victims coming from this very wide category. ${ }^{108}$

The Appeals Chamber was clearer: "for the purposes of participation in the trial proceedings, the harm alleged by a victim and the concept of personal interests under article 68 (3) of the Statute must be linked with the charges." 109 In certain circumstances, as will be discussed below, victims have a particular interpretation of the way the crime affected them that could be useful in the development of international law and of international justice. They may have experiences related to the charges that do not necessarily fall squarely within the elements of the crimes. However, if the Court does not consider that the victim's particular circumstances fall within the charges, the victim will not be allowed to participate in the trial.

The Court in the Lubanga case has taken a narrow approach to the crimes charged. ${ }^{110}$ The Court has held that "combat-related activities such as scouting, spying, sabotage and the use of children as decoys, couriers or at military check-points" ${ }^{\text {"111 }}$ constitute direct participation in hostilities, as does acting as a bodyguard for commanders or guarding military property. ${ }^{112}$ The Rome Statute Diplomatic Conference draft had a footnote to the text of arts. $8(2)(b)(x x v i i)$ and $8(2)(e)(v i i)$ that provided a narrow interpretation of the crimes:

Prosecutor v. Thomas Lubanga Dyilo, ICC-01/04-01/06, Decision on the Applications for Participation in the Proceedings of a/0001/06, a/0002/06 and a/0003/06 in the case of the Prosecutor v. Thomas Lubanga Dyilo and of the investigation in the Democratic Republic of the Congo (28 July 2006) (International Criminal Court, Pre-Trial Chamber I), online: ICC <http://www2.icc-cpi.int/ iccdocs/doc/doc192508.pdf> [Lubanga July 2006 Decision]; Prosecutor v. Thomas Lubanga Dyilo, ICC-01/04-01/06, Decision on applications for participation in proceedings a/0004/06 to a/0009/06, a/0016/06, a/0063/06, a/0071/06 to a/0080/06 and a/0105/06 in the case of The Prosecutor $v$. Thomas Lubanga Dyilo (20 October 2006) (International Criminal Court, Pre-Trial Chamber I), online: ICC $<$ http://www2.icc-cpi.int/iccdocs/doc/doc247904.pdf>.

See e.g. Lubanga July 2006 Decision, ibid. at 9; Prosecutor v. Thomas Lubanga Dyilo, ICC-01/0401/06, Decision on the Applications for Participation in the Proceedings Submitted by VPRS 1 to VPRS 6 in the Case the Prosecutor v. Thomas Lubanga Dyilo (29 June 2006) at 6 (International Criminal Court, Pre-Trial Chamber I), online: <http://www.icc-cpi.int/iccdocs/doc/doc287364.pdf> [Lubanga VPRS Application]. 2008) at para. 95 (International Criminal Court, Trial Chamber I), online: ICC <http://www2.icccpi.int/iccdocs/doc/doc409168.pdf> [Lubanga Victims’ Participation]. Lubanga Appeal, supra note 42 at para. 65. 
The words "using” and "participate" have been adopted in order to cover both direct participation in combat and also active participation in military activities linked to combat.... It would not cover activities clearly unrelated to the hostilities such as food deliveries to an airbase or the use of domestic staff in an officer's married accommodation. ${ }^{113}$

The Court has agreed with this interpretation. ${ }^{114}$ However, while the Court recognizes that children participate in the fighting, such children are not just combatants; they are also porters, guards, spies, and ammunition carriers, ${ }^{115}$ and are used to detect mines. ${ }^{116}$ Children, particularly girls, recruited into armed forces prepare food, wash and tidy, and are frequently forced to provide sexual services. ${ }^{117}$ Girls not only experience forced marriage, but rape and other "gender-based violence, including prostitution, sexual humiliation and mutilation, trafficking and domestic violence." ${ }^{118}$ Sexual violence affects boys as well, but to a lesser extent. ${ }^{119}$ Male child soldiers who have been victims of sexual violence similarly experience shame and pain. ${ }^{120}$ If the charges are limited to fighting roles, the Court will not recognize child soldier victims who are also victims of other acts perpetrated on them external to the fighting.

All four victims recognized are, or are related to, male child soldiers. They are parents of male child soldiers who participated in the conflict or they represent male child soldiers themselves. ${ }^{121}$ No female child soldiers have been recognized as victims either in the situation or in the case. The small number of victims recognized is representative of some experiences of child soldiers, but with such a small representative group, which excludes one section of child soldiers, there will be little international justice for victims if this case proceeds with only these victims. Children do not experience armed conflict in the same way. ${ }^{122}$ By excluding a section of victims who experience the crimes in a different way, the Court is excluding child soldiers from full international justice.

In addition to the limited number of victims recognized in the case, there are limitations on the extent to which victims can participate once recognized. Article 68(3) limits the participation of victims once they are recognized to where the personal interests of the victim are affected. The Appeals Chamber in the Lubanga case said that applications to be recognized to participate in a particular proceeding "should include a statement from the victims in relation to whether and how their personal interests are affected ... as well as why it is 'appropriate' for the Appeals Chamber to permit their views and concerns to be

113 Cited in Knut Dörmann, Elements of War Crimes under the Rome Statute of the International Criminal Court: Sources and Commentary (Cambridge: Cambridge University Press, 2003) at 376.

Lubanga, Confirmation of Changes, supra note 11 at para. 262.

Grossman, supra note 85 at 327.

UN Secretary-General, Promotion and Protection of the Rights of Children: Impact of Armed Conflict on Children, UN GAOR, 51st Sess., UN Doc. A/51/306 (1996) at para. 115 [Rights of Children].

Ibid. at para. 45.

Ibid. at para. 91; Park, supra note 98 at 321.

Rights of Children, supra note 116 at para. 93.

Chinkin, supra note 64 at 116.

Lubanga July 2006 Decision, supra note 106; Lubanga VPRS Application, supra note 107.

Jordan A. Gilbertson, "Little Girls Lost: Can the International Community Protect Girl Soldiers?," Comment, (2008) 29 U. La Verne L. Rev. 219 at 220. 
presented." 123 The Trial Chamber later said that "personal interest” meant an actual interest in the matters the Court was considering, and not a general interest in achieving justice. ${ }^{124}$ Victims have to demonstrate that the particular issues raised affect them. The subjective nature of the interests of the victims in relation to those crimes is contrary to the idea of the objectivity and impartiality of liberal, democratic justice. Therefore, in taking the impartial approach to justice, the Court could exclude the voices of the victims and their achievement of international justice. The constant consideration of whether personal interests are affected slows down a trial process, which means that international justice is lengthier and ultimately more difficult to attain.

In deciding whether victims' interests are in question, the Court shall also determine whether they affect the rights of the accused and the need for a fair trial. ${ }^{125}$ The accused has the right to remain innocent until proven guilty and to have a fair trial. ${ }^{126}$ In an international court, there is already a certain amount of predisposition to a finding of guilty due to the high-profile nature of the conflicts, crimes, and arrests. Adding victims to the process can further presuppose the guilt of the accused, as the victims must demonstrate that they have been harmed as a result of crimes committed within the jurisdiction of the Court. It can also disrupt the fairness of the proceedings by putting the "equality of arms" off balance. ${ }^{127}$ This is a different, but no less valid, concern in providing international justice and one which required the Court to stay the Lubanga case despite the need to provide international justice. ${ }^{128}$ The right to a fair trial for the accused is a central component of achieving international justice because if there is no just process, there can be no just outcome. If victims are given the forum to provide their views and stories on the accused, the crimes committed, and the harm that they suffered in the trial process, this may be cathartic for them, but it could influence the outcome of a usually well-regimented court procedure based on rules of evidence and procedure that ensure that an outcome is fair. The limits placed on victims currently in the Court are considered more fully in the next section, but it could be that the limited voice given to victims by the Court assists in some way in creating greater international justice overall. Something different may be required to ensure that victims have their own sense of international justice.

\section{VICTIMS’ REPRESENTATION}

One concern is that there will be too many victims, which will slow down the trial and not provide justice to the accused. The Court is wary of each victim having his or her own legal representatives. Thus, the Victims' Section must group victims under common legal

Prosecutor v. Thomas Lubanga Dyilo, ICC-01/04-01/06, Decision of the Appeals Chamber on the Joint Application of Victims a/0001/06 to a/0003/06 and a/0105/06 concerning the "Directions and Decision of the Appeals Chamber" of 2 February 2007 (13 June 2007) at para. 23, (International Criminal Court, Appeals Chamber), online: ICC <http://www2.icc-cpi.int/iccdocs/doc/doc286765.pdf>.

Compare dissenting opinion of Song J., ibid.; see also Lubanga Victims' Participation, supra note 108 at para. 96.

Rome Statute, supra note 1, art. 68(3).

Ibid., art. 66; International Covenant on Civil and Political Rights, 16 December 1966, 999 U.N.T.S. 171, art. 14 (entered into force 23 March 1976).

Susana SáCouto \& Katherine Cleary, "Victims' Participation in the Investigations of the International Criminal Court” (2008) 17 Transnat'l L. \& Contemp. Probs. 73 at 85.

Lubanga Stay of Prosecution, supra note 7 at para. 95. 
representatives. ${ }^{129}$ In selecting common legal representatives, the Victims' Section will take the views of the victims into account along with the personal interests of the victims and any conflict of interest. ${ }^{130}$ Usually the experiences of victims of even the same crime are diverse and the Court should take account of these individual experiences. ${ }^{131}$ In Lubanga, even though there are only four victims, they represent parents and child soldiers themselves and their experiences cannot be grouped together. Not every victim can tell his or her story; only the particular aspects that link them to the group will be explained. Therefore, neither the Court nor the international community will have the opportunity to understand the personal experience of victims. This will simply underline the problems that already exist with the Lubanga case in relation to the unrepresentative nature of the victims.

NGOs also often group victims together, which assists them in having representation in the Court, identifies them as possible witnesses, ${ }^{132}$ and provides them with other assistance in relation to recovery from the conflict. However, these NGOs will necessarily have their own agendas and will promote the cause of the victims in order to influence the Court in the way that the NGO wants it to proceed ${ }^{133}$ without necessarily considering the thoughts and desires of the victim whose story they are using. This brings a political aspect into the Court, which is contrary to the notion of objective justice.

One further problem with victims' representation is that the victims are separated, often geographically, from each other in remote areas of the DRC and sometimes are hard to find. The legal representatives will not be able to meet them very often and will not be able to be in contact with them constantly. Therefore, the legal representatives will not be able to receive instructions from the victims, but will rather act on the basis of how they expect the victims will want the case to run. The victims themselves may not understand the court processes and procedures and will not have an opportunity themselves to present their individual voices and stories. Thus, they do not have access to the meaningful sense of justice that the Rome Statute implies they could have had. ${ }^{134}$ They are effectively excluded from the process. ${ }^{135}$ This is compounded when the common legal representative has to present the views and interests of several victims in the course of presenting a case on the common interests of the victims.

There was a suggestion that the Court may have its opening of the Lubanga trial in the DRC. The idea was that victims could personally participate in the opening of the Court, understand the court process, and see their legal representatives at work on their behalf. This

Rules of Procedure and Evidence, supra note 30, r. 90(3); see also Situation in Uganda, ICC-02/04, Decision on legal representation of Victims a/0090/06, a/0098/06, a/0101/06 a/0112/06, a/0118/06, a/0119/06 and a/0122/06 (15 February 2008) (International Criminal Court, Pre-Trial Chamber II), online: ICC <http://www2.icc-cpi.int/iccdocs/doc/doc439437.pdf>. Regulations of the Court, supra note 60, reg. 90(4).

Pieslak, supra note 4 at 158-59.

Helen Durham, "We the People: The Position of NGOs in Gathering Evidence and Giving Witness at International Criminal Trials" in Thakur \& Malcontent, supra note 23, 169 at 174.

Danner, supra note 16 at 533.

SáCouto \& Cleary, supra note 127 at 100.

This is similar to the experiences recorded for victims in the common law criminal justice system: see Strang, supra note 26 at 11. 
idea never eventuated due to security concerns. ${ }^{136}$ Also, some victims have not been recognized in the Lubanga case because of security concerns. Additionally, victims and their supporters who put themselves forward to be recognized by the Court face security concerns, as do their lawyers. ${ }^{137}$ In being excluded from the process, the victims themselves are not personally receiving international justice. This goes against the purpose of having victims' representation in the Court.

\section{HOW CAN THE IMBALANCE OF JUSTICE BE REDRESSED?}

International justice includes ensuring accountability and ending impunity. To achieve greater accountability, victims' voices need to be heard and their dignity respected. It has been recognized in the domestic context that victims want a forum for justice in which their personal views are taken into account and where they can participate, but not too formally. ${ }^{138}$ They also want material and emotional restoration. In the international context, it has been recognized that victims of crimes, and particularly gender-based crimes, want a forum in which they can tell their stories and feel that they are being respected and heard. ${ }^{139}$ However, they do not necessarily want the "dehumanizing experience" of testifying in court. ${ }^{140}$ In a sense, the justice that victims want is symbolic — with international crimes, nothing can be done to fully make amends for the crimes committed. Nevertheless, victims want a voice in the process so that their experiences are recognized and their suffering remembered. They may also want to be involved in a process that potentially metes out punishment to their tormenters. The Court should be able to achieve justice for victims by changing the way that it deals with victims in the trial and in other aspects of the process.

Immediately after the tenth anniversary of the adoption of the Rome Statute it is appropriate to start questioning whether the Court has delivered on its initial promise of delivering international justice to victims and how it can improve. The events surrounding the commemoration of the anniversary demonstrate that the international community is aware of the challenges the Court faces in delivering international justice. ${ }^{141}$ The first case to commence in the Court, the Lubanga case, at its initial stages before it was stayed and then reopened, does not necessarily demonstrate that the Court will always proceed with considerable disregard for the rights and needs of the victims, but it could give some indication of the way the Court may be tending.

International Criminal Court, Newsletter, “An Update on the Events of The Prosecutor v. Thomas Lubanga Case” (March 2008), online: ICC < http://www2.icc-cpi.int/Menus/ICC/Reports+on+activities/ ICC+newsletter/>.

Katy Glassborow, “Intermediaries in Peril” (28 July 2008), online: Institute for War \& Peace Reporting $<$ http://www.iwpr.net/?p=acr\&s=f\&o=345909\& apc_state=henpacr $>$.

Strang, supra note 26 at 193.

Franke, supra note 15 at 818.

Ibid.

H.E. Mr. Bruno Stagno Ugarte, "Commemoration of the Tenth Anniversary of the Adoption of the Rome Statute of the International Criminal Court” (United Nations Headquarters, 17 July 2008), online: ICC $<$ http://www2.icc-cpi.int/iccdocs/asp_docs/library/asp/10ANY_pasp_17jul08_1700.pdf>. 
The Review Conference in $2010^{142}$ will be an appropriate place for the states parties to consider making international justice more accessible to victims within the Court. This section considers some changes that might be useful. It is not the place here to suggest an approach outside the framework of the Court. The Court was established to achieve international justice, and there is no doubt that there are mechanisms already in place to achieve a certain amount of justice. The question is how the arrangements could be altered to give greater effect to victims' rights and their access to international justice. Steps could be taken to expand the charges, increase the meaningfulness of victims' participation, and give recognition to the needs of victims.

\section{A. Charges}

As the stay of proceedings in Lubanga might demonstrate, the Prosecutor so far appears to have taken on too great a responsibility for ensuring international justice while excluding the rights of the accused, and thereby has failed. He has also sought to expedite proceedings and preserve resources by relying on documentary evidence rather than seeking out witnesses and evidence in the field. This has led to fewer charges against suspects before the Court, as evident in the charges that the Prosecutor has brought in the Lubanga case. The states parties at the review conference could review the role of the Prosecutor and create more accountability for the role of the Prosecutor in dealing with international organizations and with the Court. In relation to the ending of the stay, now there will hopefully be no further reliance on secret documents, and proceedings should be open to the extent that they do not impinge on the rights and security of victims and witnesses. In relation to the charges that the Prosecutor brings against suspects, the Prosecutor should clarify why charges are limited and why the range of offences under the Rome Statute is not addressed in each circumstance. If the Court considers that the offences do not address the majority of the crimes that were committed in the conflict and the needs of the victims of that conflict, it should request the Prosecutor to add more charges at the confirmation of charges phase.

In the Lubanga case, for example, if it now proceeds, the Court could use the opportunity of the delay in the proceedings to ask the Prosecutor to expand the charges to include rape and other sexual violence. Through expanded charges, child soldiers who have been subject to sexual violence, and other victims of the conflict, such as women who have been raped, forced into marriage, and women and men who have been disfigured or damaged by the conflict, have more chance of being recognized. The Court would therefore be better able to address more fully the events that occurred in the conflict and give greater justice to the victims of the conflict.

In the interest of expediency of the trial, the Court may wish to keep the charges that are already there. This need not exclude the consideration of sexual violence and other violence in the context of child soldiers. Once again, it would not be a function of the review conference; rather the Court itself could take the opportunity of the reopening of the trial to be expansive and give broad interpretations to the Rome Statute. In other words, the Court

142 See International Criminal Court, Assembly of States Parties, Venue of the Review Conference, ICCASP/7/Res.2 (2008), online: ICC < http://www2.icc-cpi.int/iccdocs/asp_docs/Resolutions/ICC-ASPASP7-Res-02-ENG.pdf>. 
could read into the crimes of conscripting, enlisting, and using child soldiers the real experience of the children forced to be soldiers, including not only the combat nature of their experience, but also the forced marriages, the rapes, and the other forms of exploitation and abuse as explained above.

The UN Special Representative of the Secretary-General on Children in Armed Conflict has said:

\begin{abstract}
When the Special Representative spoke to girl combatants in the eastern DRC, they spoke of being fighters one minute, a "wife" or "sex slave" the next, and domestic aides and food providers at another time. Children are forced to play multiple roles, asked to kill and defend, carry heavy burdens, spy on villages and transmit messages. ${ }^{143}$
\end{abstract}

The UN Special Representative submitted to the Court a document with observations on the charges of enlisting, conscripting, and using child soldiers. ${ }^{144}$ She suggested that the charges should be read broadly, as a process rather than a single act. For example, conscription is a process that involves the forcing of children to join, their indoctrination, and their training. ${ }^{145}$ This all occurs before they learn to use weapons, and should be included within the examination of the charges. It has also been found that often exploitation of girls, in terms of both domestic labour and sexual slavery, maintained the armed group's capacity to continue fighting. ${ }^{146}$ The UN Special Representative gave the example of a girl who was raped and forced to work as a domestic before eventually taking part in military attacks. ${ }^{147}$ Her experience of rape was part of the process of conscription, and therefore the judges should consider that experience in their determination of the charges.

The Special Representative's submission to the Court highlighted the fact that the Court, in seeking to narrowly define the charges, excluded many child soldiers, and particularly female child soldiers. ${ }^{148}$ The Court should reinterpret the crimes of enlistment, conscription, and use of child soldiers so as to give a voice to the other experiences of child soldiers and to highlight the severe nature of the crimes that go beyond the harm of the battlefield. In that way, the Court could provide international justice to more child soldiers and others affected by the conflict.

\title{
B. VICTIMS
}

In Lubanga, the Court held that the children were specifically recruited to participate in the armed conflict, were trained for that purpose, and used in that way. ${ }^{149}$ While the Court held that there were many victims involved, ${ }^{150}$ it failed to accord to victims the rights that are theirs under the Rome Statute. As has been seen, victims have rights under the Rome Statute 
where their personal interests are affected. This should mean that individual victims of crimes before the Court should be given a voice, but so far, too often the voice of victims has been silenced. This can lead to disempowerment rather than the intended goal of empowerment. The victim's voice is disregarded, or there is a lack of security or understanding felt by the victim in the process. ${ }^{151}$ With the promise of the Court being open to victims, the Court is thus far failing to deal with victims in a way that gives them real voice - they are represented by counsel, never see the Court, have security concerns, and do not necessarily understand the full implications of their involvement.

Given these serious problems, one solution could be to take away the main victim representation and participation provisions. The purpose of the participation of victims was to give them international justice. Where that international justice is not fulfilled there is a great sense of disappointment in the Court. Instead of trying to involve victims in the Court process fully, which leads to accusations of a lack of international justice for the other participants and a lack of a fair trial for the accused, a different approach should be taken. It could be best to return to a more symbolic involvement of victims, or rather an involvement where victims can express their experiences, but not "disrupt" the efficiency, effectiveness, and fairness of a trial. Victims could still be involved in the situation phase of the cases, but not participate directly in the trial of a particular defendant until the end. ${ }^{152}$ This drastic step in changing the scope of the Court's activities might need further consideration based on the outcome of cases that are currently before the Court, but it is worth considering briefly at present, given the current state of the Lubanga case.

The situation phase involves investigation of the possible crimes and the production of evidence. Victims could participate in a general situation hearing at which they could give a statement outlining their experiences and be heard as to the harm that they have suffered and are suffering as a result of the crime and the conflict. This would take away the legalistic nature of victims' claims, remove the need for multiple representatives, and limit harm to the rights of the accused, as at that stage there would be no accused. The benefits to the Court and the Prosecutor would be that the victims' stories would set the scene for the crimes that they would be investigating; they would be able to highlight areas in which further investigation is needed; and they could determine which victims could prove to be valuable witnesses. In this way, victims would be involved in the court process and have their stories directly heard in a meaningful way, but they would not need to be involved in the trial of a particular accused which, as has been seen, does not provide international justice to victims.

The reparations part of victims' participation has yet to be tested, but it is conceivable that victims could be more involved in sentencing. Their experiences and the harm they may have suffered could influence the punishment imposed, which would give the victims a sense of international justice as well as limiting the harm that their involvement could do to the rights of the accused. Victims should also still be able to receive reparations. The criteria for recognition of victims in the reparations stage could be recognition in the situation phase and some additional criteria relevant to the charges for which the accused is convicted. In that way, victims could receive concrete recognition and assistance in minimizing as far as 
possible their suffering as a result of the conflict and crimes, and thus obtain some form of international justice.

\section{Alternatives Within The Court System}

A new body, the Trust Fund for Victims, has been established for victims, which recognizes the particular needs of victims of the serious crimes with which the Court deals. In some ways, the Trust Fund can go more towards providing meaningful justice in the form of restoration of victims' dignity and rights than can a court conviction. The Trust Fund itself recognizes the role it plays in international justice: "We [and the Court] are united behind the goal of justice for victims of the most serious crimes." ${ }^{153}$ The Trust Fund is an independent body set up under the Rome Statute ${ }^{154}$ for two roles: to distribute reparations at the end of the trial to recognized victims; and to provide assistance to victims who are not recognized by the Court as victims in the situation or the case, but have been recognized to be victims of the general armed conflict or situation in the states in which the Court is conducting investigations.

The Trust Fund has a Board of Directors, which manages the funds under the Regulations of the Trust Fund for Victims, ${ }^{155}$ adopted by the Assembly of States Parties to the Rome Statute. States, corporations, and individuals provide funds through voluntary contributions. At present, funds cannot be earmarked and the donors have little say regarding where the money goes. In that sense, the Trust Fund is unaccountable and non-democratic (although the Board is accountable to the Assembly of States Parties), but in terms of victim participation as a form of democracy, the Trust Fund consults with victims and victim representatives in the field to determine what the funds can best be used for.

The reparations role will be conducted under court orders after sentencing. ${ }^{156}$ The immediate role of assisting victims is carried out through partnerships with NGOs and specialist bodies in the field after approval from the Court. ${ }^{157}$ Its purpose is to provide practical assistance to victims of the conflict in general to enable them to rebuild their lives:

Acknowledging the atrocities through projects like memorials helps the psychological healing of individuals and families. Funding medical treatment for victims with disfiguring injuries reduces the stigma they face and facilitates their reintegration. Counselling helps families accept children who were abducted or women and girls who were raped, and it promotes reconciliation among families and communities. ${ }^{158}$

The Trust Fund is, at present, constrained by a lack of funds, lack of recognition within the Court, and the focus that the Court has placed on its role. In the situation in the DRC, the

International Criminal Court, Victims Trust Fund, "Who We Are: Our Link to the International Criminal Court," online: ICC <http://wwwold.icc-cpi.int/vtf.html>.

$154 \quad$ Rome Statute, supra note 1, art. 79.

155 International Criminal Court, Assembly of States Parties, Regulations of the Trust Fund for Victims, ICC-ASP/4/Res.3 (2005), art. 59, online: ICC <http://www2.icc-cpi.int/NR/rdonlyres/35400D3-A8D342A4-9922-83C61A953175/144116/ICCASP4Res3_English.pdf>.

156 Rules of Procedure and Evidence, supra note 30, r. 98(2).

157 Ibid., r. 98(4); Regulations of the Trust Fund for Victims, supra note 155, arts. 60, 69-72.

158 International Criminal Court, Victims Trust Fund, "What We Do: Funding or Implementing," online: ICC < http://wwwold.icc-cpi.int/vtf/vsfmeetings.html>. 
Court held that the projects that the Trust Fund wanted to undertake in that region would provide a benefit to victims. They said that they "do not violate the presumption of innocence or prejudice the rights of the accused, and the fairness and impartiality of the trial," "159 thereby not affecting the interests of justice of the accused. The Court further held that the Trust Fund had to ensure that it would have enough funds to pay out reparations for victims arising out of court cases, which the Court held to be the most important part of the Fund's mandate. ${ }^{160}$ The Court ordered the Trust Fund to conduct a study anticipating the resources that it would need to provide reparations. This decision has limited the scope of the Trust Fund at this stage to address the needs of victims of the conflicts with which the Court is dealing outside of the courtroom.

The Trust Fund has an important role to play in advocating for victims and their needs in the international community. It also has an essential role, through partnerships in the field, in restoring victims back, as near as possible, to the situation that they were in before they became victims. The Trust Fund is just starting, and is likely to be the subject of review at the review conference. At the conference, the role of the Trust Fund should be consolidated. The mandate to help victims who are not represented in the court proceedings should be strengthened and a separate budget should be developed for reparations outside of the work that the Fund does in the field. With these changes, the Trust Fund could contribute effectively to meaningful international justice for victims.

\section{CONCLUSION: SCOPE FOR FUTURE CHANGE?}

The UN Secretary-General, Ban Ki-moon, has said in the context of the commemorations of the tenth anniversary that "[t]oday, the United Nations work to promote peace, development and human rights is heavily dependent on the ICC's efforts to advance justice and establish the rule of law." 161 This places a burden on the Court to live up to the international community's broad desire for international peace and security, while also focusing on the needs of the individuals caught up in conflicts. It means that the Court and the international community will need to make changes to include a different recognition of international justice for victims in terms of their individual human rights. The review conference will need to address the issue of the advancement of international justice, among other things, by taking into account victims' rights in a different manner that recognizes their stories and experiences.

The International Criminal Court is a complex body that aims to cover in its scope a wide range of international criminal law, cases, and interests of states, victims, and accused. This article has only been able to draw out one aspect of the Court as demonstrative of a certain

159 Situation in the Democratic Republic of Congo, ICC-01/04, Decision on the Notification of the Board of Directors of the Trust Fund for Victims in accordance with Regulation 50 of the Regulations of the Trust Fund (11 April 2008) at 5 (International Criminal Court, Pre-Trial Chamber I), online: ICC $<$ http://www2.icc-cpi.int/iccdocs/doc/doc470235.pdf $>$. Ibid. at 7.

161 UN Secretary-General Ban Ki-moon, Speech, (Commemoration of the Tenth Anniversary of the Adoption of the Rome Statute of the International Criminal Court, United Nations Headquarters, 17 July 2008), online: ICC <http://www2.icc-cpi.int/iccdocs/asp_docs/Library/asp/Speech-UNSG-18jul081810.pdf $>$. 
failure at this stage in its implementation of the promise of international justice that the Court brought at its inception; that is, justice for victims. This article has considered the following factors that may assist in defining international justice: accountability, ending impunity, giving voice to victims, and respecting their dignity as human beings who have suffered through serious international crimes. Despite a promise of delivering on these features, ${ }^{162}$ the Court has so far not delivered any justice to victims. Instead, if the Lubanga case is indicative of how trials will proceed, few victims will be recognized as victims. The charges will be limited and exclude many victims and aspects of the victims' stories. Victims will therefore have a limited opportunity for their voices to be heard before the Court.

The purpose of including victims in the trial process was to rectify these concerns and place the victims' stories at the forefront of the case. However, as has been seen, there are numerous problems with the way that the Court has approached victim participation. Therefore, in order to address the imbalance, it could be in the interests of justice for victims to be removed from the trial except as witnesses with appropriate protection. Instead, they should be given the forum at the investigation or situation phase to attend court or have their lawyer represent them, give statements of their experiences, influence the development of evidence and charges at that stage, and then receive reparations at the end. Other alternatives also need to be developed further and given an expanded role, such as the Trust Fund for Victims. If such steps are taken, after another ten years the Court might not necessarily represent a failure of international justice for victims. Ironically, by removing victims from the trial process and opening up other means of engagement, the Court could prove to offer greater international justice for victims and certainly much less disappointment for such victims when it fails to achieve international justice. 